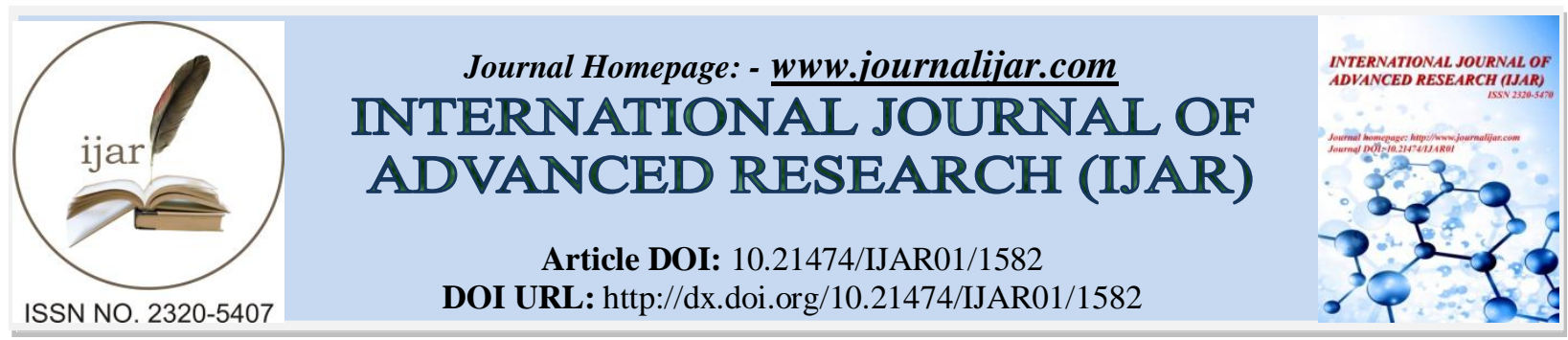

RESEARCH ARTICLE

\title{
EFFECT OF DIFFERENT METHODS OF TRAINING ON PHYSIOLOGICAL VARIABLES AMONG SCHOOL STUDENTS.
}

\author{
Dr. K. Divya. \\ Assistant Professor, Alagappa University College of Physical Education, Karaikudi.
}

\section{Manuscript Info}

Manuscript History

Received: 12 July 2016

Final Accepted: 26 August 2016

Published: September 2016

Key words:-

yogic practice, saq training, resting pulse rate, vo2 max.

\begin{abstract}
The purpose of the study was to find out the Effects of different methods of training on physiological variables among school students. To achieve this purpose of the study forty five students studying in alagappa metric $\mathrm{hr}$ sec school, karaikudi were randomly selected as subjects. The age of the subjects were ranged between 15 to 17 years. The selected subjects were divided in to three equal groups of fifteen subjects each. Group I ( $1^{\text {st }}$ Method of training) underwent yogic practice, Group II ( $2^{\text {nd }}$ Method of training) underwent SAQ Training for five days per week for six weeks. Group III acted as control that did not participate in any training. The following physiological variables namely Resting pulse rate, $\mathrm{VO}_{2}$ max were selected as dependent variables. All the subjects of three groups were tested on selected dependent variables. The analysis of co-variance was used to analyze the significant different, if any among the groups. Since, three groups were compared whenever they obtained ' $F$ ' ratio for adjusted post test was found to be significant, the scheffe's Post hoc test to find out the paired mean difference, if any. The 0.05 level of confidence was fixed as the level of significance to test the ' $\mathrm{F}$ ' ratio obtained by the analysis of covariance which was considered as an appropriate.
\end{abstract}

\section{Introduction:-}

It is a programme of exercise designed to improve the skills and increase the energy capacity of an athlete for a particular event. "Sports training aims at achieving high performance in sports competitions. It is a process which is spread over a long period of time and is a competition cum performance oriented endeavor as well". Asana means holding the body in a particular posture to bring stability to the body and poise to the mind. The practices of asana bring purity in tabular channels firmness to the body and vitality to the body and the mind. Term pranayama in yoga, is often translated more specifically as "breath control". Literal translations include "suspension of breath" and regulation of breath". For the purpose of this study, a set of pranayama and yoga asana were considered. SAQ Training These wonderful acts of speed, agility and quickness are what make the different between winning and losing. The programme also has other significant benefits such as improving eye hand and foot co-ordination, strength and explosive power, VO2 max, and resting heart rate as well as being full of variety and great fun. 


\section{Methodology:-}

The purpose of the study was to find out the Effects of different methods of training on physiological variables among school students. To achieve this purpose of the study forty five students studying in Alagappa Metric. $\mathrm{Hr}$ .Sec. School, karaikudi, Tamilnadu were randomly selected as subjects. The age of the subjects were ranged between 15 to 17 years. The selected subjects were divided in to three equal groups of fifteen subjects each. Group I underwent yogic practice, Group II underwent SAQ Training for five days per week for six weeks. Group III acted as control that did not participate in any training. Resting pulse rate and vo2 max were selected as dependent variable.digital blood pressure monitor was used to measure Resting Pluse rate in beats per minute and Multi Stage Shuttle Run Test was used to measure vo2 max and the unit of measurement was recorded in $\mathrm{ml} / \mathrm{kg} / \mathrm{min}$.

The following physiological variables namely resting pulse rate, $\mathrm{VO}_{2}$ max were selected as dependent variables. All the subjects of four groups were tested on selected dependent variables at prior to and immediately after the training programme. The analysis of covariance was used to analyze the significant different, if any among the groups. Since, three groups were compared whenever they obtained ' $F$ ' ratio for adjusted post test was found to be significant, the scheffe's Post Hoc test to find out the paired mean difference, if any. The 0.05 level of confidence was fixed as the level of significance to test the ' $F$ ' ratio obtained by the analysis of covariance which was considered as an appropriate.

\section{Computation Of Analysis Of Covariance Of Resting Pulse Rate:-}

\begin{tabular}{|c|c|c|c|c|c|c|c|c|}
\hline Test & $\begin{array}{l}\text { Exp. } \\
\text { Group I }\end{array}$ & $\begin{array}{l}\text { Exp. } \\
\text { Group II }\end{array}$ & $\begin{array}{l}\text { Control } \\
\text { Group }\end{array}$ & $\begin{array}{l}\text { Source } \\
\text { of Variance }\end{array}$ & $\begin{array}{l}\text { Sum } \\
\text { of Squares }\end{array}$ & Df & $\begin{array}{l}\text { Mean } \\
\text { Squares }\end{array}$ & OF Value \\
\hline \multicolumn{9}{|c|}{ Pretest } \\
\hline Mean & 75.20 & 75.40 & 75.00 & Between & 1.20 & 2 & 0.60 & \multirow[t]{2}{*}{0.36} \\
\hline S.D. & 1.22 & 1.25 & 1.26 & Within & 70.00 & 42 & 1.67 & \\
\hline \multicolumn{9}{|c|}{ Post test } \\
\hline Mean & 72.80 & 68.40 & 74.73 & Between & 316.04 & 2 & 158.02 & \multirow[t]{2}{*}{$120.82^{*}$} \\
\hline S.D. & 1.22 & 0.61 & 1.34 & Within & 54.93 & 42 & 1.31 & \\
\hline \multicolumn{9}{|c|}{ Adjusted Post test } \\
\hline \multirow[t]{2}{*}{ Mean } & \multirow[t]{2}{*}{72.80} & \multirow[t]{2}{*}{68.42} & \multirow[t]{2}{*}{74.87} & Between & 336.70 & 2 & 168.35 & \multirow[t]{2}{*}{$298.71^{*}$} \\
\hline & & & & Within & 23.11 & 41 & 0.56 & \\
\hline
\end{tabular}

* Significant at .05 level of confidence is 2 and 42 and 2 and 41 are 3.222 and 3.226 respectively).

Ordered Scheffe's Post Hock Test Mean Differences On Resting Pulse Rate Among Three Groups (Scores in beats per minute)

\begin{tabular}{|l|l|l|l|l|}
\hline $\begin{array}{l}\text { Experimental Group } \\
\text { I }\end{array}$ & $\begin{array}{l}\text { Experimental Group } \\
\text { II }\end{array}$ & $\begin{array}{l}\text { Control } \\
\text { Group }\end{array}$ & $\begin{array}{l}\text { Mean } \\
\text { Differences }\end{array}$ & $\begin{array}{l}\text { Confidence Interval } \\
\text { Value }\end{array}$ \\
\hline 72.80 & 68.27 & - & $4.53^{*}$ & 0.693 \\
\hline 72.80 & - & 74.87 & $2.07^{*}$ & 0.693 \\
\hline- & 68.27 & 74.87 & $6.60^{*}$ & 0.693 \\
\hline
\end{tabular}

* Significant at .05 level of confidence.

Computation Of Analysis Of Covariance Of $\mathrm{Vo}_{2} \mathrm{Max}$

\begin{tabular}{|c|c|c|c|c|c|c|c|c|}
\hline Test & $\begin{array}{l}\text { Exp. } \\
\text { Group I }\end{array}$ & $\begin{array}{l}\text { Exp. } \\
\text { Group II }\end{array}$ & $\begin{array}{l}\text { Control } \\
\text { Group }\end{array}$ & $\begin{array}{l}\text { Source of } \\
\text { Variance }\end{array}$ & $\begin{array}{l}\text { Sum } \\
\text { of Squares }\end{array}$ & $\mathrm{df}$ & $\begin{array}{l}\text { Mean } \\
\text { Squares }\end{array}$ & OF Value \\
\hline \multicolumn{9}{|l|}{ Pretest } \\
\hline Mean & 68.27 & 68.13 & 68.07 & Between & 0.31 & 2 & 0.16 & \multirow[t]{2}{*}{0.33} \\
\hline S.D. & 0.68 & 0.72 & 0.57 & Within & 19.60 & 42 & 0.47 & \\
\hline \multicolumn{9}{|c|}{ Post test } \\
\hline Mean & 71.20 & 75.07 & 68.40 & Between & 336.18 & 2 & 168.09 & \multirow[t]{2}{*}{$307.84 *$} \\
\hline S.D. & 0.91 & 0.68 & 0.49 & Within & 22.93 & 42 & 0.55 & \\
\hline \multicolumn{9}{|c|}{ Adjusted Post test } \\
\hline \multirow[t]{2}{*}{ Mean } & \multirow[t]{2}{*}{71.16} & \multirow[t]{2}{*}{75.07} & \multirow[t]{2}{*}{68.43} & Between & 334.28 & 2 & 167.14 & \multirow[t]{2}{*}{$331.59 *$} \\
\hline & & & & Within & 20.67 & 41 & 0.50 & \\
\hline
\end{tabular}

* Significant at .05 level of confidence is 2 and 42 and 2 and 41 are 3.222 and 3.226 respectively). 
Ordered Scheffe's Post Hock Test Mean Differences On Vo $\mathrm{o}_{2}$ Max Among Three Groups (Scores in liter.min ${ }^{-1}$ )

\begin{tabular}{|l|l|l|l|l|}
\hline Experimental Group I & Experimental Group II & $\begin{array}{l}\text { Control } \\
\text { Group }\end{array}$ & Mean Differences & $\begin{array}{l}\text { Confidence Interval } \\
\text { Value }\end{array}$ \\
\hline 71.16 & 75.07 & - & 3.91 & 0.655 \\
\hline 71.16 & - & 68.43 & 2.73 & 0.655 \\
\hline- & 75.07 & 68.43 & 6.64 & 0.655 \\
\hline
\end{tabular}

* Significant at .05 level of confidence

\section{Discussion On Findings:-}

The SAQ training will enhance these qualities. Adequate SAQ Training keeps the students to produce power and increasing the capacity for speed generation throughout training.

The results of the present study indicate employed that the significant differences were noticed between yogic practice and SAQ training when compared to control group on selected criterion variables such as resting pulse rate (reduction) and $\mathrm{VO}_{2}$ max. Resting pulse rate was highly favored to significantly improved (reduction) due to the influence of yogic practice group. $\mathrm{VO}_{2}$ max was significantly improved due to the influence of yogic practice and SAQ training group when compared with control group.

\section{Conclusions:-}

It can be concluded that the yogic practice may lead to greater improvements in resting pulse rate better than the SAQ training and VO2 max highly favored to SAQ training than that of yogic practice.

\section{Reference:-}

1. Hardayal Singh (1984), Sports Training General Theory and Methods Published by the Publication Unit.

2. Fox, Edward L. Richar W. Bowers and Merle. Foss. The Physical Basic for Exercise and Sports. Dubuque: W.M.C. Brown Communications Inc., 1993. 